\title{
Globalisation and Human Rights: An Overview of its Impact
}

\author{
Shabina Arfat \\ Faculty of Law, University of Kashmir, Srinagar, Kashmir, J\&K, India
}

\begin{abstract}
The development of human rights law in response to globalization is not new, and there is nothing inherent in the international system that would prevent further protective measures. A number of U.N. specialized agencies have also addressed the question of globalization. This global development is sometimes viewed as being responsible for exploitation, and other forms of human rights abuses. On the other hand, improvements in human rights are sometimes attributed to the spread of liberal ideas and movements, which is one of the key dimensions of globalization. Critics say human rights have been adversely affected by globalization for instance right to equality and other socio economic rights. The commitment of the United Nations to the indivisibility of human rights is reflected in the Universal Declaration of Human Rights. Human rights are the first responsibility of governments. While globalization offers great opportunities, the fact that its benefits are very unevenly shared and its costs unevenly distributed represents an aspect of the process that affects the full enjoyment of all human rights, in particular in developing countries. Inequality has risen during this present globalization period. In this paper an attempt has been made to highlight the impact of globalization on human rights regime.
\end{abstract}

Keywords: development, economic rights, globalisation, human rights, inequality

\section{Introduction}

Global development is sometimes viewed as being responsible for disenfranchisement, exploitation, and other forms of human rights abuses (Rabet, Delphine, 2009). On the other hand, improvements in human rights are sometimes attributed to the spread of liberal ideas, which is one of the key dimensions of globalization (Rosenau, 2003). On the one hand, many (Evans \& Tony, 1999) argue that economic integration in trade and investment generates incentives for governments to abuse poor and disenfranchised people, so that repression, exploitation and human rights abuses arise. Economic freedom refers to the internal liberalization of economic rights, such as the "freedom to engage in economic transactions, without government interference but with government support of the institutions necessary for that freedom, including rule of law, sound money, and open markets" (Dreher, Gassebner \& Siemers, 2010). Globalization is a multidimensional phenomenon, comprising "numerous complex and interrelated processes that have a dynamism of their own" (U.N, 2000). It involves a deepening and broadening of rapid transboundary exchanges due to developments in technology, communications, and media (UN, 2001). Such exchanges and interactions occur at all levels of governance and among non-state actors, creating a more interdependent world (Steiner \& Alston, 2000).

Human rights violations continue to be the norm rather than the exception. According to Amnesty International (2006), millions of people worldwide are still denied fundamental rights (Dreher, Gassebner, Lars \& Siemers, 2010). Development poses challenges to international human rights law, because for the most part that law has been designed to restrain abuses by powerful states and state agents. While globalization has enhanced the ability of civil society to function across borders and promote human rights, other actors have gained the power to violate human rights in unforeseen ways. International human rights law aims primarily to protect individuals and groups from abusive action by states and state agents.

The authors of Global Issues (Rajamoorthy, Undated) states that globalization resulted in the violation of the fundamental right to work. In 1995, the ILO announced that one third of the world's willing to work population was either unemployed or underemployed. Globalization has also resulted in informalization of labor. Only $8 \%$ of the labor force in India is in the formal economy while $90 \%$ work in the informal economy with no legal protection or security and are subject to ruthless exploitation. Many companies, including TNCs (transnational companies) got rid of their unionized labor force and moved their operations to low wage and depressed areas to avail themselves of the large supply of unorganized and unprotected, mainly female labor. Mathews George Chunakara describes the state of workers in developing countries after globalization as a race to the bottom, and the bottom means slave like conditions. He explains this by the search of transnational companies for cheap labor in order to maximize 
their profits, so the governments of developing countries compete for the investors by providing cheaper labor. International Statistics (Global Issues, Poverty Facts and Stats) shows that:

-Half the world -nearly three billion people - live on less than two dollars a day

-The wealthiest nation on earth has the widest gap between rich and poor of any industrialized nation -The top fifth of the world's people in the richest countries enjoy $82 \%$ of the expanding export trade and $68 \%$ of foreign direct investment -while the bottom fifth, barely more than $1 \%$

-In 1960, the $20 \%$ of the world's people in the richest countries had 30 times the income of the poorest $20 \%$ and in 1997,74 times.

-A few hundred millionaires now own as much wealth as the world's poorest 2.5 billon people.

-The combined wealth of the world's 200 richest people hit \$ 1 trillion in 1999; the combined incomes of the 582 million people living in the 43 least developed countries is $\$ 146$ billion.

In Asia, in particular, the migration of large numbers of female workers to the Middle East from, for example, West Asia, and South-East Asia, has had a strong impact both socially and economically. It has been estimated, for example, that the ratio of females to males who comprise migrant labour is 12:1 among Filipinos migrating to Asian destinations; 3:1 among Indonesians and 3:2 among Sri Lankans (Riham el-Lakany, 1999). Many of these women work as domestic workers, seamstresses, nurses, assistants in retail shops and restaurants, and as entertainers oftentimes in the sex industry (Robinson, 1997). While most women have the opportunity of earning higher wages than at home, labour conditions and mechanisms of both social and physical security in receiving countries seem to be perilous at best. More often than not, receiving States tend not to observe even minimal labour standards with regard to migrant workers, particularly women. Heavy economic dependence of the sending States on the inward monetary remittances of migrant workers has inhibited them from demanding fair labour conditions and protection from receiving States, thereby further weakening the position of such workers. Women have entered the workforce in large numbers in States that have embraced liberal economic policies. One United Nations survey concludes that "it is by now considered a stylized fact that industrialization in the context of globalization is as much female-led as it is export led" (United Nations, 1999). The overall economic activity rate of women for the age group 20-54 approached 70 per cent in 1996. The highest absorption of women has been witnessed in the export-oriented industrial sector. Such industries are also labour intensive, service oriented and poorly paid (Hilary, 1999). Thus, according to the Women's Environment and Development Organization (WEDO) women bear the disproportionate weight of the constraints introduced under the yoke of globalization (Riham el-Lakany, 1999).

According to the World Bank report, some 2 million people were forced to leave from their land because of huge infrastructure development projects funded by World Bank from 1986 to 1993. As many as $80 \%$ of those displaced were in Asia. Mega projects which take land from people include dams, seaports, airports, highways, bridges, industrial estates, golf courses and other types of resort, prawn farming and all kinds of plantation. All these massive development projects have been promoted by TNCs in collaboration with local governments. The Asian region, the growth centre of the world, has been the main target of such mega development projects (Chunakara, Undated \& Samithy, 2000).

\section{International Response}

In his report to the UN Millennium Summit, Kofi Annan, described the world of globalization, “... as a new context for and a new connectivity among economic actors and activities throughout the world. Globalization has been made possible by the progressive dismantling of barriers to trade and capital mobility, together with fundamental technological advances and steadily declining costs of transportation, communication and computing. Its integrative logic seems inexorable, its momentum irresistible (Robinson, 2002)."

When globalization is interpreted as internationalization, the term refers to a growth of transactions and interdependence between countries. From this perspective, a more global world is one where more messages, ideas, merchandise, money, investments and people cross borders between national-state-territorial units. A second common analytical dead-end in discussions of globalization has equated the notion with liberalization. In this case, globalization denotes a process of removing officially imposed restrictions on movements of resources between countries in order to form an 'open' and 'borderless' world economy. On this understanding, globalization occurs as authorities reduce or abolish regulatory measures like trade barriers, foreign-exchange restrictions, capital controls, and visa requirements (Scholte, 2002).

The development of human rights law in response to globalization is not new, and there is nothing inherent in the international system that would prevent further protective measures. The resulting movement led to the creation of the ILO in 1919. Unlike all subsequent international organizations, the ILO engaged all the relevant actors in its operations from the beginning. Using a tripartite structure of representation, the ILO ensured the participation of business, labor, and governments in developing worker rights and 
minimum labor standards for member states. While the standards adopted are addressed to member states for implementation, compliance requires the cooperation of the non-state actors as well, because the organization primarily aims to respond through regulation to poor treatment of labor by private industry. Such regulation is made easier by the participation of labor and business in the lawmaking and supervisory procedures of the ILO. The international protection of civil and political rights emerged later, becoming an aim of the international community at the end of World War II in response to the atrocities committed during that conflict.

A number of U.N. specialized agencies have also addressed the question of globalization. The ILO has long tackled the phenomenon. From the Copenhagen Social Summit in 1995 to the 1998 Declaration on Fundamental Principles and Rights at Work, the ILO has pressed for an international consensus on the content of the core labor standards that provide a social floor to the global economy. In 1998, the ILO adopted the Convention concerning the Prohibition and Immediate Action for the Elimination of the Worst Forms of Child Labour (Convention No. 182). It also adopted its Declaration on Fundamental Principles and Rights at Work together with a follow-up procedure based upon technical cooperation and reporting. The principles have been incorporated into codes of conduct by the private sector and also used as a basis for action by various regional communities, such as the Southern African Development Community and the Caribbean Community. U.N. bodies and specialized agencies, such as the U.N. Children's Fund (UNICEF), the U.N. Educational, Scientific and Cultural Organization (UNESCO), the Office of the U.N. High Commissioner for Refugees (UNHCR), and the U.N. Environment Programme (UNEP), have all carried out work that has implications for the overall response by the U.N. to the phenomenon of globalization. On the regional level, the European Union, in the context of negotiations for the fourth Lom Agreement with countries of Africa, the Caribbean, and the Pacific (ACP states), sought to include good governance in public affairs, democracy, respect for human rights, and respect for the rule of law, essential in the elements of the accord, with the termination of assistance for non-respect of any of the elements.

Jurists are analysing the issue whether globalization impacts on the implementation of human rights as stated in the Universal Declaration of Human Rights (1948) and the subsequent United Nations agreements, particularly the covenant on civil and political rights (1966), the covenant on economic, social and cultural rights (1966) and the declaration on the right to development (1986). They often relate one aspect of human rights to the other aspect of globalization for instance relating poverty in developing countries to debt or relating unemployment to privatization, or relating health deterioration to the monopoly of medicine patents. They also enumerate the aspects of deteriorations in human rights, such as impoverishment and lowering standards of living, increasing inequality, discrimination, deprivation of satisfaction of basic needs such as food, clean water, housing, and illiteracy.etc. The impact of the adverse consequences of globalization on the enjoyment of human rights is multidimensional; all aspects of human existence be they political, economic, social or cultural, are affected. The negative impact on one dimension of human rights, e.g. economic rights, necessarily has a domino effect on other rights. This reality reinforces the principle enunciated in the Vienna Declaration and Programme of Action, 1993 that human rights are "universal, indivisible, interdependent and interrelated" (Oloka-Onyango \& Udagama, 1999). Today, international human rights obligations have to be viewed through the prism of this fundamental principle. The Charter of the United Nations recognizes the important linkages between the maintenance of international peace and security, the establishment of conditions of economic and social progress and development, and the promotion and protection of universal human rights (Charter of the United Nations, 1945). A singularly important development is the imposition by the Charter of a legal obligation on Member States to take joint and separate action in cooperation with the Organization to promote, inter alia, higher standards of living, full employment and conditions of economic and social progress and development, and universal respect for, and observance of, human rights (Charter of the United Nations, 1945). Action taken by Member States, either collectively or singly, to defeat this pledge is clearly a violation of the Charter, which under certain circumstances may amount to violations of principles of jus cogens.

The Copenhagen Declaration and Programme of Action, while recognizing the benefits of globalization, cautions: "At the same time, the rapid processes of change and adjustment have been accompanied by intensified poverty, unemployment and social disintegration. Threats to human well-being, such as environmental risks, have also been globalized. Furthermore, the global transformations of the world economy are profoundly changing the parameters of social development in all countries. The challenge is how to manage these processes and threats so as to enhance their benefits and mitigate their negative effects upon people" (Report of the World Summit for Social Development, 1995). These very same sentiments are expressed in the Statement of the Committee on Economic, Social and Cultural Rights on globalization issued in May 1998 (International Human Rights Reports, 1999). It 
calls on the World Bank, the IMF and WTO to devise methods of measuring the impact of their policies on the enjoyment of economic, social and cultural rights (social monitoring) and to revise those policies accordingly (Globalizing Economy Meeting, 2000).

The U.N. General Assembly Resolution "International Convention on the Protection of the Rights of All Migrant Workers and Members of their Families" (1990) contained direct verbiage in regards to the protection of migrant workers and their families from exploitation and servitude, stating that migrants and their families "shall have the freedom of thought, conscience and religion". In 2001, U.N. Secretary General, Kofi Annan, urged universal ratification on International Migrants Day (December 18), noting: ...the fate of many migrants lies in stark contrast to the aspirations reflected in the Universal Declaration of Human Rights, human rights norms and labor conventions (Waldron, 2010).

The commitment of the United Nations to the indivisibility of human rights is reflected in the Universal Declaration of Human Rights. This instrument recognizes the right to an adequate standard of living, social security, the right to work and just and favourable conditions of work, and the right to education, in addition to traditional civil and political rights. Significantly, the Universal Declaration of Human Rights also recognizes the right of everyone to a social and international order in which the rights and freedoms set forth in it can be fully realized (Art. 28). Furthermore, the Universal Declaration of Human Rights explicitly recognizes that nothing in it may be interpreted as implying a right to destroy any of the recognized rights. The International Covenants on Economic, Social and Cultural Rights (ICESCR) and on Civil and Political Rights (ICCPR) further elaborate upon the foundation laid by the Universal Declaration of Human Rights. Both have been ratified by large numbers of States and are extremely important in pinpointing the specific legal obligations of State actors with regard to all aspects of human rights protection.

The right to development is of equal importance when examining the human rights implications of globalization. The international community through the General Assembly has recognized the right to development as an inalienable human right (Declaration on the Right to Development). The United Nations Declaration on the Right to Development recognizes that the central focus of the process of development is the human person, who should be the active participant and beneficiary of the right to development. Development itself is recognized as a multifaceted process that embraces the development of economic, social, cultural and political aspects of human life (Article 2). This position is affirmed by the widely respected Human Development Index advocated by UNDP as a means of realistically assessing levels of development. It is also affirmed by the Copenhagen Declaration and Programme of Action (1995) on social development (Report of the World Summit for Social Development, 1995).

The UNDP Human Development Report 1999 argues that reaping the benefits of a globalized economy cannot be done by merely forcing countries to open up their economies. To make the most of those benefits there has to be a policy package. Governments have to ensure that sound policies for social development and protection, poverty eradication, income distribution and environmental protection are put in place, just as well-thought-out macroeconomic policies and institutions have to be established to ensure sound economic management. In the absence of that combination, sustained and sustainable development will remain illusory. It is also the case - as successive waves of financial crises have taught that sound social policies have to be in place in order to absorb the shock of the vagaries of market forces (United Nations Development Programme, Human Development Report, 1999). The report also calls for a reorientation of global governance that ensures equity in international negotiations and that has as its central focus human development and human rights.

According to the report of Committee on Economic, Social and Cultural Rights, on the right to food appears to deal with the issue of food security within the context of globalization (General Comment, 1999). Significantly, it draws attention to the responsibilities of private actors, aside from the obligation of States parties to appropriately regulate their conduct, in the realization of the right to adequate food. The comment goes on to stipulate that "the private business sector - national and transnational - should pursue its activities within the framework of a code of conduct conducive to respect of the right to adequate food, agreed upon jointly with the Government and civil society". Furthermore, it calls upon the IMF and the World Bank to pay attention to the protection of the right to food in drawing up lending policies, credit and structural adjustment programmes.

In a resolution on the question of the impact of globalization and its effect on human rights, the United Nations General Assembly recognizes that: 'while globalization offers great opportunities, the fact that its benefits are very unevenly shared and its costs unevenly distributed represents an aspect of the process that affects the full enjoyment of all human rights, in particular in developing countries' (UN). The United Nations General Assembly emphasizes that: 'While globalization, by its impact on, inter alia, the role of the state, may affect human rights, the promotion and protection of all human rights is first and foremost the 
responsibility of the state' (UN). It is put forward here that the Declaration on the Right to Development sets out a national and global framework of responsibility for states to do so. Human rights discourse has also been devoted to the study of multinational corporations and their direct effect on human rights (Addo, 1999; Kamminga, \& Zia Zarifi, 2000; 2002).

\section{Impact of Globalisation on Human Rights}

There are group of "human rights" in the form of economic rights, labor rights, cultural rights, civil and political rights etc. The globalization is considered to have an impact on the following rights (Sykes, 2003) as:

-The admission to the WTO of nations that violate human rights extinguishes opportunities for valuable sanctions to discourage such violations.

-Open trade causes production to relocate to areas where environmental standards are lax and results in environmental degradation. Likewise, the competitive pressures that result from open trade cause regulators to lose control over local regulatory matters and precipitate a race to the bottom over matters such as social welfare standards, environmental standards, and worker protection legislation.

-Open trade exacerbates inequality in the distribution of income.

Similarly the negative impact of globalization especially on vulnerable sections of the community results in the violation of various rights guaranteed by various Covenants in particular on the;

-the enjoyment of fundamental aspects of the right to life,

-freedom from cruel, inhuman or degrading treatment,

-freedom from servitude, the right to equality and non-discrimination,

-the right to an adequate standard of living (including the right to adequate food, clothing and housing),

-the right to maintain a high standard of physical and mental health,

- the right to work accompanied by the right to just and fair conditions of labour,

-freedom of association and assembly and the right to collective bargaining, have been severely impaired.

Developing States are, more often than not, compelled by the dynamics of globalization to take measures that negatively impact on the enjoyment of those rights (Oloka-Onyango \& Udagama, 1999). Globalization has not caused "developing" countries to catch up with the developed world. Inequality has risen during this present globalization period. The developed world - their intellectuals and policy makers - view globalization as "providing good opportunities for their countries and their people." Globalization can be preserved from two angles. One angle is that globalization is a means of increasing the wealth of nations and promoting international trade. However, globalization is a direct cause for the widening economic gap between "developing" countries and "developed" countries (Waldron, 2010). There is relationship between globalization and equality and non-discrimination in a more concrete fashion. The two concepts are central to the corpus and ethos of human rights instruments and practice. The Universal Declaration and other human rights instruments are unequivocal in their declaration that all persons are equal, and that the right to nondiscrimination is a basic and fundamental human right. Inequality and discrimination unfortunately existed long before globalization was recognized as a distinct phenomenon on the international scene (Oloka-Onyango \& Udagama, 1999).

Among the distinct groups of society upon whom globalization's impact has been most telling, women clearly stand out. Few observers will deny that the general issue of gender relations globally, and the question of women's human rights specifically, has undergone significant transformation. Spurred on by the various international conferences, declarations and, most significantly, by the Convention on the Elimination of All Forms of Discrimination against Women, the respect for and recognition of women's human rights has made significant advances worldwide. The phenomenon of globalization adds greater complexities to this quest, particularly in the economic arena, but also within the context of culture and politics.

Women in the agricultural sector have also been adversely affected by the promotion of export-oriented economic policies, trade liberalization and TNCs' activities in agriculturerelated industries. Emphasis on export crops has displaced women workers in certain countries from permanent agricultural employment into seasonal employment. Subsistence farming has been severely affected in the new economic environment, leaving women farmers to seek seasonal employment (United Nations, 1999). Aside from the tenuous and low economic returns of seasonal agricultural employment, the Food and Agriculture Organization of the United Nations (FAO) has noted that the destruction of subsistence farming, increased industrial pollution and the loss of land to large commercial ventures, often financed by TNCs, have given rise to grave problems relating to food security and the health of the rural poor (Food and Agriculture Organization of the United Nations, 1998).

It is increasingly becoming clear that it is no longer tenable to draw a neat distinction between the nature of State obligations with regard to civil and political rights on the one hand, and economic, social and cultural rights on the other. United 
Nations human rights mechanisms have debunked the traditional view that civil and political rights entail only negative obligations, while economic, social and cultural rights give rise to the more complex issue of positive State obligations which require resources to be expended. The United Nations Human Rights Committee has interpreted certain rights guaranteed by the ICCPR as entailing positive obligations. This is clearly the case with regard to the right to life. In General Comment 6 (16) on article 6, the Committee interpreted (Report of the Human Rights Committee, 1982) the right to life in a broad manner that requires States parties to take positive action, e.g. to reduce infant mortality, to increase life expectancy and to take measures to eliminate malnutrition and epidemics (McGoldrick, 1991).

The negative effects of corporations on human rights in development can be divided into two categories. First, the corporation may directly violate human rights by itself or in conjunction with another actor. This typically involves civil and political rights, such as the right to personal security. For example, a corporation may hire state security forces to protect its facilities that engage in torture as occurred in Myanmar in association with Unocal Corp.29 Also, a corporation may directly violate rights by prohibiting collective bargaining or discriminating against minorities. The second category concerns indirect effects. This involves the corporation's influence on host governments. Corporations can undermine the state's ability to fulfill human rights law. They use their influence to encourage governments to adopt policies of liberalization, deregulation and privatization that ignore human rights consequences. This second effect concerns mostly economic, social and cultural rights, which are vital in developing states. Corporations are the engines of economic growth upon which states depend for the provision of the right to development. Increasingly, corporations are more economically powerful and influential than the developing host-states from which they extract their profits.

Members of the World Trade Organization when negotiating and implementing international rules on trade liberalization, should bear in mind their concurrent obligations to promote and protect human rights, mindful of the commitment made in the Vienna Declaration 1993, that human rights are the first responsibility of governments. While the WTO agreements provide a legal framework for the economic aspects of the liberalization of trade, the norms and standards of human rights balance this by offering a legal framework for trade liberalization's social and ethical dimensions.

The human rights violations resulting from globalization are failures of governance. Human rights law is capable of monitoring and regulating foreign investment. Respect for human rights requires governments to protect, promote and fulfill obligations. The right to development process can provide a framework focused on the implementation of a rights-based approach to development. The right to development is versatile and promotes global responsibility for globalization. The Declaration on the Right to Development requires states to guarantee rights in a manner applicable to globalization. In order to be universal and remain relevant, human rights law must protect those marginalized by the exigencies of globalization by empowering local peoples (De Feyter, 2005). Development strategy consists of liberal trading regimes with a reduced role for the state. Despite the new challenges arising from the globalization process and, the state remains the only full subject of international law responsible under human rights law. It is the state, acting individually or collectively, that ultimately controls international relations.

The protection of rights generally requires a legal system that is effective and credible, and such systems do not come free. Moreover, many rights require some additional sacrifice of other human wants-minimum wages, rights to unionize, environmental standards, and social security systems, for example, all come at the price of an increase in the cost of goods and services, or an increase in taxation. Not all effects of globalisation will infringe "human rights," but some of them may (Sykes, 2003).

\section{Conclusion}

In an age of globalization, the struggle for human rights has become more complex and challenging. Realizing human rights especially economic and social rights is becoming increasingly difficult. One of the most profound challenges that we face as a community of nations is to understand better the emerging socio-economic forces and forms of globalization, to shape them to serve our needs and to respond effectively to their deleterious consequences. Human rights can balance forces of globalisation within a just international legal framework. Maintaining balance between globalisation and protection of human rights should be a priority. Human rights are what make us human. They are the principles by which we create the sacred home for human dignity. Human rights are what reason requires and conscience commands.

\section{Suggestions}

-A global watch should be established to monitor and report the unethical transactions that take place between the governments of developing nations and global corporations. The governments of 
developing nations should not continue to get rich by selling their factors of production (land, labor) to global corporations.

-Requirements to become a free trading nation should be revised. Present requirements eliminate many developing countries. Developed countries need to do more to assist by making it easier for developing countries to benefit from trade and investments.

-Treaty-based mechanism focusing on the responsibilities of multilaterals as well as private actors in protecting human rights is an extremely significant step in the current economic environment.

-Efforts by states to create investment rules must be subjected to scrutiny and analyzed through human rights discourse.

\section{References}

Addo, M. (1999). Human rights standards and the responsibility of transnational corporations. (Eds.) The Hague: Kluwer Law International.

Charter of the United Nations (1945), Preamble, articles 55- 56.

Chunakara, M., G. (2000). Globalization and its impact on human rights, Christian Conference of Asia, Hong Kong. Christava Sahitya Samithy, Tiruvalla. The Indian Edition. Ted and Winnie Brock. Retrieved from: http://www.daga.org/press/ia/ glob/glob06.htm

De Feyter, K. (2005). Human rights: Social justice in the age of the market. Zed Books, 2

Declaration on the Right to Development (1986). General assembly resolution 41/128 of 4 December 1986 .

Dreher A., Gassebner, M., \& Siemers, H. R. (2010). Globalization, economic freedom and human rights. centeer for european, governance and economic development research. Retrieved from: http://www.personal.umich.edu/ alandear/glossary/e.html

Evans, Tony (1999). Trading human rights. In A. Taylor and C. Thomas (Edit). Global trade and global social issues, 3152. London: Routledge.

Food and Agriculture Organization of the United Nations (1998). Rural women and food security: Current situation and perspectives, 43-44.

General Comment (1999). The right to adequate food, committee on economic, social and cultural rights. Report on the twentieth and twenty-first Sessions, Economic and Social Council Official Records 2000, supplement No. 2.

Global Issues, Poverty Facts and Stats. (n.d). Retrieved from: http://www.globalissues.org/Traderelated/Facts.asp

Globalizing Economy Meeting (2000). The role of the committee on economic, social and cultural rights. In A Globalizing Economy meeting on 6 May 2000 at Palais Wilson.

Hilary, J. (1999), Globalization and employment: New opportunities, real threats. Panos Briefing, No. 33, p. 1.

International Human Rights Reports (1999). Human Rights Reports, 6(4), 1176.

Kamminga, M. \& Zarifi Z., S., (2000), Liability of multinational corporations under international law. (Eds.) The Hague: Kluwer Law International.
McGoldrick, D. (1991). The human rights committee: Its role in the development of the international covenant on civil and political rights, Clarendon Press, 329-330.

Oloka-Onyango, J., \& Udagama, D.. (1999). The realization of economic, social and cultural rights: Globalization and its impact on the full enjoyment of human rights, Preliminary report, Sub-Commission resolution 1999/8.

Rabet, Delphine (2009). Human rights and globalization: The myth of corporate social responsibility? Journal of Alternative Perspectives in the Social Sciences, 1(2), 463-75.

Rajamoorthy (Undated). Development and Human Rights. Retrieved from: http://www.daga.org/press/ia/glob/ glob04.htm

Report of the Human Rights Committee (1982). Official records of the general assembly, Thirty-seventh Session, Supplement No. 40, (A/37/40), annex V.

Report of the World Summit for Social Development (1995) Copenhagen. United Nations publication, Sales No. E.96.IV.8), chap. I, resolution 1, annex I and II.

Report of the World Summit for Social Development (1995). Copenhagen, 6-12 March 1995, United Nations publication, Sales No. E.96.IV.8), chap. I.

Riham el-Lakany (1999). WTO trades off women's rights for bigger profits, women's environment and development organization (News \& Views), 12 (2 \&3), 11.

Robinson, L., N. (1997). The globalization of female child prostitution: A call for reintegration and recovery measures via article 39 of the United Nations convention on the rights of the child. Indiana Journal of Global Legal Studies, 5(1), 239.

Robinson, M. (2002). UN high commissioner for human rights ethics. human rights and globalization second global ethic lecture. The Global Ethic Foundation University of Tübingen, Germany.

Rosenau, James N. (2003). Distant proximities: Dynamics beyond globalization. Princeton: Princeton University Press.

Steiner, H., \& Alston, P. (2000). International Human Rights in Context (ed.) 940.

Stephens, B. (2002). The amorality of profit: transnational corporations and human rights'. Berkeley Journal of International Law, 20, 45.

Sykes, A., O. (2003). International trade and human rights: An economic perspective. The Chicago Working Paper Series Index. University of Chicago Law School. Retrieved from: http://www.law.uchicago.edu/Lawecon/index.html

U.N. (2000). Globalization and its impact on the full enjoyment of all human rights: Preliminary report of the secretaryGeneral, U.N. GAOR, 55th Sess., 5.

U.N..(2001). The U.N. general assembly has called globalization "not merely an economic process but one that has social, political, environmental, cultural and legal dimensions which have an impact on the full enjoyment of all human rights, G.A. Res. 55/102, U.N.

UN (2005). Globalization and its impact on the full enjoyment of all human rights. 'UNGA,

United Nations (1999). World Survey on the Role of Women in Development: Globalization, Gender and Work. United Nations Publication, Sales No, pp. 11-12.

United Nations Development Programme (1999). Human development report. Oxford University Press, 1999, chapter 4 \& 5 .

Waldron S., M. (2010). Globalization and its impact on the development and protection of human rights evaluations and Recommendations. Guyana Journal, Retrieved from: http:// www.guyanajournal.com 